\title{
PERFORMANCE AND CARCASS TRAITS OF BROILERS SUPPLEMENTED WITH PROBIOTIC OR NEOMYCIN ANTIBIOTIC
}

\author{
H.Y. El-Hammady ${ }^{1}$, M. El-Sagheer ${ }^{1+}$, H.H.M. Hassanien ${ }^{2}$ and H.A. Hassan ${ }^{2}$ \\ 1- Department of Poultry Production, Faculty of Agriculture, Assiut University, 71526 Assiut, Egypt \\ *Corresponding author: (sagheer68@yahoo.com), 2- Department of Animal and Poultry Production, Faculty \\ of Agriculture, South Value University, 83523 Qena, Egypt
}

\section{SUMMARY}

An experiment was conducted designed to evaluate the effect of a probiotic as alternative to antibiotic growth promoters for broiler chicks. One hundred and fifty unsexed one-day-old Ross broiler chicks were randomly assigned to five equal groups; the first was considered the control group, while the second to fifth was the treatments groups. Each group included three equal replicates each of 20 chicks. The ration used in the first group was the experimental ration without any supplements (control) while, those of 2-5 treatment groups were the same ration, but supplemented with antibiotic Neomycin $(200 \mathrm{mg} / \mathrm{kg}$ diet $)$, probiotic $(1 \mathrm{~g} / \mathrm{kg}$ diet $)$, probiotic $(1.5 \mathrm{~g} / \mathrm{kg}$ diet), and probiotic $(2 \mathrm{~g} / \mathrm{kg}$ diet), respectively. All birds were raised in wire floored batteries with the following dimensions: width: $97 \mathrm{~cm}$; length: $50 \mathrm{~cm}$; height: $45 \mathrm{~cm}$ under similar environmental and management conditions. Body weight $(B W)$, body weight gain $(B W G)$, feed intake (FI), feed conversion ratio (FCR); carcass and some organ weights percentages as well as intestines and ceca lengths were determined at the end of the experiment (42 days of age). The obtained results revealed that birds fed ration supplemented with antibiotic (G2), achieved significantly heavier final BW and higher BWG than birds received different levels of probiotic (G3 to G5) or the control diet (G1). However, birds received $1 \mathrm{~g}$ or $1.5 \mathrm{~g}$ probiotic/kg diets (G3 or G4) had significantly higher final BW and BWG than those fed the probiotic diet (G5) and the control diet (G1). Birds fed antibiotic diet (G2) or received $1 \mathrm{~g}$ and $1.5 \mathrm{~g}$ probiotic/kg diets (G3 and G4) had significantly better FCR values than those of birds fed the control diet (G1) and $2 \mathrm{~g}$ probiotic/kg diet (G5). The total mortality rate of birds in G3 was lower than those of the other groups. Supplementing the diets with antibiotic or probiotics did not affect the percentages of carcass and body organ weights (gizzard, liver, heart, spleen and Giblets) as well as the lengths of intestines and ceca. The abdominal fat percentage in G1 and G4 was decreased compared to the other groups. Therefore, the supplementation of $1.5 \mathrm{~g}$ probiotic/kg diet as an alternative to antibiotics in broiler diet is highly recommended to obtain higher growth performance, improved feed conversion, and lower mortality, without adverse effect on abdominal fat and carcass traits.

Keywords: Probiotic, antibiotic, broilers, performance, carcass

\section{INTRODUCTION}

Antibiotics have been used in animal agriculture after their discovery in the 1950's (Fuller, 1989). Dietary antibiotics are reported to have beneficial effects on animal and poultry growth, feed conversion efficiency and the inhibition of pathogen growth (Gaskins et al., 2002). However, the extensive use of antibiotics caused an antibiotic residue problem in poultry meat and increased proportion and persistence of antibiotic resistant fecal bacteria (Fuller, 1989; Turnidge, 2004).

Many research studies have reported feed residues in chicken meat products and development of bacterial resistance to antibiotics used in both human medicine and poultry production. Therefore, since January 2006, European Union banded the trade and use of antibiotics in food producing animals, and escalated the search for alternatives to be used within the poultry industry (Janardhana et al., 2009). In this respect, Gibson and Roberfroid (1995) stated that the use of compounds that may have probiotic effects is a possible way to improve intestinal health and animal performance in the absence of antibiotic growth promoters.

Probiotics are live microbial feed supplements, which improve the intestinal microbalance (Jernigan and Miles, 1985). Probiotics are multi-strain compounds containing live microbes to establish, enhance or re-establish essential microflora in the gut. Probiotics are a highly concentrated pre-mix containing seven strains of bacteria (Lactobacillus planetarium, Lactobacillus bulgaricus, Lactobacillus acidophilus, Lactobacillus rhamnosus, Bifidobacterium bifidum, Streptococcus thermophilus, and Enterococcus faecium). All microorganisms in the probiotics are naturally occurring and have been isolated from a wide range of feed, plant, animal, bird and human sources. Moreover, probiotic is reported to be safe, non-toxic and residual free.

According to International Animal Health (1999), there were no risks due to overdosing since the probiotic is compatible with all feeds, feed ingredients like vitamins and minerals and some antibiotics. Cyberhorse (1999), stated that probiotic can be used in a wide range of circumstances, to improve the general health of animals, address specific problems and maximize animal's performance. The authors added that under general conditions, probiotic has been promoted to: improve health naturally, stimulate appetite, aid in 
establishment of gut flora in immature animals like one day old chicks, re-establish gut microflora after antibiotic treatment, optimize digestion of feed and reduce stress. Many studies on the efficacy of probiotics on animal growth and performance revealed positive (Correa et al., 2003) and none or negative effects (Lima et al., 2003). The present study aimed to evaluate broilers performance using under different levels of probiotic in order to find out the most suitable ones and their possibility as alternatives to antibiotics in broiler production.

\section{MATERIALS AND METHODS}

\section{Experimental Birds:}

One hundred and fifty unsexed one-day-old Ross broiler chicks were wing banded, individually weighed and randomly distributed into 5 equal groups, (control and 4 treatments). Each group included three replicates of 10 chicks each.

\section{Experimental groups:}

The first group (G1) was fed commercial broiler diet without supplementation (control), while the second, to fifth groups (G2 to G5) were the treatments groups, in which birds were fed diets containing $200 \mathrm{mg}$ Neomycin/kg diet, $1 \mathrm{~g}$ probiotic $/ \mathrm{kg}$ diet, $1.5 \mathrm{~g}$ probiotic $/ \mathrm{kg}$ diet, and $2 \mathrm{~g}$ probiotic $/ \mathrm{kg}$ diet, respectively.

\section{Management:}

The birds were raised in battery cages with the dimensions: width: $97 \mathrm{~cm}$; length: $50 \mathrm{~cm}$; height: 45 $\mathrm{cm}$ in a closed broiler house under standard management trial conditions. Chicks were exposed to 24 continuous lighting hours by using incandescent lambs, 60 watt hanged at a level of $180 \mathrm{~cm}$ from the floor. Feed and water were available ad libitum all the time. Light intensity was gradually reduced to be around 10 LUX by 21 days of age. The relative humidity was kept at $50-60 \%$. Thermo neutral temperatures were maintained throughout the experiment. They were $32^{\circ} \mathrm{C}$ for $\mathrm{d} 1$ to $3,30^{\circ} \mathrm{C}$ for $\mathrm{d}$ 4 to $6,28^{\circ} \mathrm{C}$ for $\mathrm{d} 7$ to $10,26^{\circ} \mathrm{C}$ for $\mathrm{d} 11$ to $14,24^{\circ} \mathrm{C}$ for 15 to $21 \mathrm{~d}$ and $22^{\circ} \mathrm{C}$ thereafter. All Chicks were vaccinated for Newcastle disease at 7, 18 and $28 \mathrm{~d}$ and Gumboro disease at $12 \mathrm{~d}$. Birds were fed a starter diet from 1 to $21 \mathrm{~d}$ and a grower diet from 22 to 42 . The composition and calculated analysis of the experimental diets are shown in Table (1).

Table 1. Composition and calculated analysis of experimental broiler diets

\begin{tabular}{|c|c|c|c|c|c|c|c|c|c|c|}
\hline \multirow{2}{*}{ Items } & \multicolumn{5}{|c|}{ Starter diet (0-3 wks) } & \multicolumn{5}{|c|}{ Grower diet (4-6 wks) } \\
\hline & G1 & G2 & G3 & G4 & G5 & G1 & G2 & G3 & G4 & G5 \\
\hline \multicolumn{11}{|l|}{ Ingredients (\%) } \\
\hline Yellow corn & 62.00 & 61.98 & 61.90 & 61.85 & 61.80 & 67.00 & 66.98 & 66.90 & 66.85 & 66.80 \\
\hline Soybean meal $(44 \% \mathrm{CP})$ & 27.80 & 27.80 & 27.80 & 27.80 & 27.80 & 20.00 & 20.00 & 20.00 & 20.00 & 20.00 \\
\hline $\begin{array}{l}\text { Corn gluten meal } \\
(60 \% \mathrm{CP})\end{array}$ & 6.32 & 6.32 & 6.32 & 6.32 & 6.32 & 8.30 & 8.30 & 8.30 & 8.30 & 8.30 \\
\hline Dicalcium Phosphate & 1.90 & 1.90 & 1.90 & 1.90 & 1.90 & 1.93 & 1.93 & 1.93 & 1.93 & 1.93 \\
\hline Limestone & 1.29 & 1.29 & 1.29 & 1.29 & 1.29 & 1.34 & 1.34 & 1.34 & 1.34 & 1.34 \\
\hline Sodium chloride & 0.10 & 0.10 & 0.10 & 0.10 & 0.10 & 0.10 & 0.10 & 0.10 & 0.10 & 0.10 \\
\hline DL-Methionine & 0.14 & 0.14 & 0.14 & 0.14 & 0.14 & 0.23 & 0.23 & 0.23 & 0.23 & 0.23 \\
\hline L-Lysine & 0.19 & 0.19 & 0.19 & 0.19 & 0.19 & 0.48 & 0.48 & 0.48 & 0.48 & 0.48 \\
\hline Vit. \& Min. Premix ${ }^{1}$ & 0.25 & 0.25 & 0.25 & 0.25 & 0.25 & 0.25 & 0.25 & 0.25 & 0.25 & 0.25 \\
\hline Sand & 0.01 & 0.01 & 0.01 & 0.01 & 0.01 & 0.37 & 0.37 & 0.37 & 0.37 & 0.37 \\
\hline Probiotic $^{2}$ & 0.00 & 0.00 & 0.10 & 0.15 & 0.20 & 0.00 & 0.00 & 0.10 & 0.15 & 0.20 \\
\hline Antibiotic $^{3}$ & 0.00 & 0.02 & 0.00 & 0.00 & 0.00 & 0.00 & 0.02 & 0.00 & 0.00 & 0.00 \\
\hline \multicolumn{11}{|l|}{ Calculated Analysis ${ }^{4}$} \\
\hline ME (kcal/ kg diet) & 3000 & 3000 & 3000 & 3000 & 3000 & 3152 & 3152 & 3152 & 3152 & 3152 \\
\hline Crude protein $(\%)$ & 23 & 23 & 23 & 23 & 23 & 21 & 21 & 21 & 21 & 21 \\
\hline Calcium (\%) & 1.00 & 1.00 & 1.00 & 1.00 & 1.00 & 1.00 & 1.00 & 1.00 & 1.00 & 1.00 \\
\hline Available phosphorus (\%) & 0.50 & 0.50 & 0.50 & 0.50 & 0.50 & 0.50 & 0.50 & 0.50 & 0.50 & 0.50 \\
\hline Lysine (\%) & 1.16 & 1.16 & 1.16 & 1.16 & 1.16 & 1.28 & 1.28 & 1.28 & 1.28 & 1.28 \\
\hline Methionine (\%) & 0.52 & 0.52 & 0.52 & 0.52 & 0.52 & 0.59 & 0.59 & 0.59 & 0.59 & 0.59 \\
\hline
\end{tabular}

G1 to G5: Control, $200 \mathrm{mg}$ Neomycin/kg diet, $1 \mathrm{~g}$ probiotic/kg diet, $1.5 \mathrm{~g}$ probiotic/kg diet, $2 \mathrm{~g}$ probiotic/kg diet, respectively.

${ }^{1}$ Provided per kilogram of diet: vitamin A, $5500 \mathrm{IU}$; vitamin E, $11 \mathrm{IU}$; vitamin D3, $1100 \mathrm{IU}$; vitamin $\mathrm{B}_{2}, 4.4 \mathrm{mg}$; ca pantothenate, $12 \mathrm{mg}$; nicotinic acid, $44 \mathrm{mg}$; choline chloride, $191 \mathrm{mg}$; vitamin $\mathrm{B}_{12}, 12.1 \mu \mathrm{g}$; vitamin $\mathrm{B}_{6}, 2.2 \mathrm{mg}$; thiamine (as thiamine mononitrate), $2.2 \mathrm{mg}$; folic acid, $0.55 \mathrm{mg}$; d- biotin, $0.11 \mathrm{mg}$; Mn, $60 \mathrm{mg} ; \mathrm{Zn}, 50 \mathrm{mg} ; \mathrm{Fe}, 30 \mathrm{mg}$; Cu, $5 \mathrm{mg}$; Se, $0.3 \mathrm{mg}$. ${ }^{2}$ Prebiotic provided per gram: Lactobacillus planetarium, $1.26 \times 10^{8} \mathrm{CFU}$; Lactobacillus bulgaricus, $2.06 \times 10^{8} \mathrm{CFU}$; Lactobacillus acidophilus, 2.06 x10 ${ }^{8}$ CFU; Lactobacillus rhamnosus, $2.06 \times 10^{8} \mathrm{CFU}$; Bifidobacterium bifidum, $2.00 \times 10^{8} \mathrm{CFU}$; Streptococcus thermophilus, $4.10 \times 10^{8} \mathrm{CFU}$; Enterococcus faecium, $6.46 \times 10^{8}$ CFU. ${ }^{3}$ Antibiotics (200 mg Neomycin $/ \mathrm{kg}$ diet). ${ }^{4}$ According to NRC (1994). 


\section{Parameters studied criteria:}

Birds of each replicate were biweekly weighed on individual basis and the body weight gain (BWG) was calculated as the difference between final and the initial body weight. Feed intake (FI) for each replicate was calculated weekly as the difference between the amount of offered feed and its remaining. The amount of consumed feed per bird was adjusted by taking in consideration the dead birds. The mean feed conversion ratio (FCR) was biweekly calculated by dividing total feed consumed by the total body weight gain of birds per each replicate. Numbers of dead bird were recorded daily and the mortality rate was calculated for each treatment. The following performance parameters were measured: feed intake (FI), weight gain (WG), and feed conversion ratio (FCR) for the cumulative periods of 1-14, 15-28, 29 - 42 and 1-42 days of age.

At the end of the experimental period (42 days of age), nine birds per group (three birds around the average weight of each replicate) were fasted for 8 hours and slaughtered. After complete bleeding, the birds were scalded and feathers were mechanically plucked. The internal organs (heart, liver, empty gizzard and spleen) were removed and weighed. Also, intestines and Ceca were lengthened. Carcass weights including giblets were calculated as percentage of pre-slaughter live body weight, while body organs (heart, liver, gizzard, giblets and spleen) were calculated as percentages of carcass weight. The abdominal fat was removed, weighed and calculated as percentage of carcass weight.

\section{Statistical analysis:}

Data were statistically analyzed by ANOVA using the General Linear Model (GLM) Procedure of SAS software (SAS institute, version 9.1, 2005). Duncan's multiple range test (Duncan, 1955) was used to detect differences among means of different groups. The following model was fitted: $Y_{i j}=\mu+T_{I}$ $+R_{j}+$ eij. Where: $Y_{i j}=$ observed value of the concerned treatment. $\mu=$ observed mean for the concerned treatment. $T_{i}=$ effect due to treatment. $R_{j}=$ the effect due to replicate. $E_{i j}=$ the error related to individual observation.

\section{RESULTS AND DISCUSSION}

\section{Body weight:}

Data on body weight (BW) are presented in Table (2). At $2^{\text {nd }}$ week, birds of the control, (G1) achieved significantly higher BW than those of G2 and G4, while there were no significant differences $(\mathrm{P} \leq 0.05)$ between groups 1,3 and 5 . At $4^{\text {th }}$ week, birds of G3 had significantly heavier BW than those of groups 1 , 2, 4 and 5. At 42 days of age, birds fed antibiotic (G2) are superior compared to the other treatments and the control one. However, birds fed diets supplemented with 1 or $1.5 \mathrm{~g}$ probiotic/kg diet (G3 or G4) had significantly heavier final BW than those fed probiotic diet (G5) and the control diet (G1). Many researchers reported that dietary antibiotics associated with improved poultry growth and inhibited growth of pathogens (Gaskins et al., 2002; Jalaludeen et al., 2005 and Sun et al., 2005).

Table 2. Live body weight (g) and total mortality rate (TMR) as affected by dietary Neomycin antibiotic and different levels of probiotics

\begin{tabular}{|c|c|c|c|c|c|c|}
\hline $\begin{array}{c}\text { Treatment } \\
\text { Age }\end{array}$ & G1 & G2 & G3 & G4 & G5 & $\begin{array}{c}\text { Significance } \\
\text { level }\end{array}$ \\
\hline Day old & $45.2 \pm 0.4$ & $45.0 \pm 0.7$ & $45.7 \pm 0.7$ & $44.5 \pm 0.6$ & $46.0 \pm 0.3$ & 0.4552 \\
\hline $2^{\text {nd }}$ weeks & $562.0^{\mathrm{a}} \pm 1.2$ & $523.8^{\mathrm{c}} \pm 7.0$ & $552.2^{\mathrm{ab}} \pm 5.6$ & $523.2^{\mathrm{c}} \pm 1.7$ & $536.0^{\mathrm{ab}} \pm 8.9$ & 0.0024 \\
\hline $4^{\text {th }}$ weeks & $1430.3^{\mathrm{b}} \pm 6.1$ & $1405.2^{\mathrm{c}} \pm 1.5$ & $1483.3^{\mathrm{a}} \pm 1.7$ & $1436.7^{\mathrm{b}} \pm 3.3$ & $1381.7^{\mathrm{d}} \pm 5.8$ & 0.0001 \\
\hline $6^{\text {th }}$ weeks & $2396.1^{\mathrm{c}} \pm 2.0$ & $2501.7^{\mathrm{a}} \pm 1.2$ & $2461.7^{\mathrm{b}} \pm 19.8$ & $2446.7^{\mathrm{b}} \pm 14.8$ & $2363.9^{c} \pm 8.7$ & 0.0001 \\
\hline TMR (\%) & 2.20 & 1.10 & 1.10 & 0.00 & 1.10 & \\
\hline
\end{tabular}

Means $( \pm \mathrm{SE})$ in the same row with different superscripts are significantly different $(\mathrm{P} \leq 0.05)$.

Values in each row are means for 3 replicates of each treatment (30 birds per each).

G1 to G5: Control, $200 \mathrm{mg}$ Neomycin $/ \mathrm{kg}$ diet, $1 \mathrm{~g}$ probiotic/kg diet, $1.5 \mathrm{~g}$ probiotic/kg diet, $2 \mathrm{~g}$ probiotic/kg diet, respectively.

Regarding the effect of probiotics, Ignatova et al. (2009) found a significant improvement in BW due to the use of probiotics in broilers. Jalaludeen et al. (2005) reported that the $0.025 \%$ probiotic supplemented birds had a significantly heavier body weight and weight gain. Inconsistent results have been reported in some literature for the effects of probiotics on broiler growth performance. EL-Nagmy et al. (2007) found the positive effects for the probiotics since they improved the absorption of nutrients and increased significantly the broiler body weight as well as depressed the harmful bacteria that cause the growth depression. Numerous studies showed that probiotics have positive effects on chicken performance (Maiolino et al., 1992 and Mountzouris et al., 2007). However, others (Yang et al., 2008) did not find such positive effects.

\section{Body weight gain}

Data of body weight gain (BWG) are presented in Table 3. During 0-2 weeks of age, the birds of G1 and G3 had significantly heavier BWG than those in G2 and G4, while there were no significant differences $(\mathrm{P} \leq 0.05)$ between groups 1,3 and 5 . During 3-4 weeks of age, the birds of G3 achieved significantly higher BWG than those in the other 
groups (G1, G2, G4 and G5). During 5-6 and 0-6 weeks of age, birds fed antibiotic (G2) had significantly higher BWG than those fed different levels of probiotic diets (G2 to G5) or the control diet (G1). However, birds fed $1 \mathrm{~g}$ or $1.5 \mathrm{~g}$ probiotic/kg diets (G3 or G4) had significantly higher BWG than those fed probiotic (G5) and control diets (G1), during 0-6 weeks of age. This is in agreement with the findings of Contrearas-Castillo et al. (2008), who stated that supplementation of antibiotic to the feed, resulted in significantly higher BWG (1-40 days) than those of the other treatments $(1 \mathrm{~g}$ probiotic/kg, $0.5 \mathrm{~g}$ probiotic $/ \mathrm{kg}$, and $0.05 \mathrm{~g}$ probiotic $/ \mathrm{kg}$ and control diets). Islam et al. (2004) found that the supplementation of $2 \mathrm{~g}$ probiotic/10 liters of drinking water led to higher $(\mathrm{P} \leq 0.05) \mathrm{BWG}$ of broiler in all treatments as compared to the treatment with $1 \mathrm{~g}$ and $3 \mathrm{~g}$ probiotics/10 liters of drinking water as well as the control diet. In contrast, the results are oppositely to those of Correa et al. (2003).

Table 3. Daily body weight gain (g/bird) as affected by dietary Neomycin antibiotic and different levels of probiotics.

\begin{tabular}{lcccccc}
\hline $\begin{array}{c}\text { Treatment } \\
\text { Age }\end{array}$ & G1 & G2 & G3 & G4 & G5 & $\begin{array}{c}\text { Significance } \\
\text { level }\end{array}$ \\
\hline $\mathbf{0 ~ - 2 ~ w e e k s ~}$ & $36.9^{\mathrm{a}} \pm 0.7$ & $34.2^{\mathrm{c}} \pm 0.6$ & $36.2^{\mathrm{a}} \pm 0.3$ & $34.2^{\mathrm{c}} \pm 0.8$ & $35.0^{\mathrm{ab}} \pm 0.9$ & 0.0085 \\
$\mathbf{3 - 4}$ weeks & $62.0^{\mathrm{cd}} \pm 0.1$ & $63.0^{\mathrm{c}} \pm 0.5$ & $66.5^{\mathrm{a}} \pm 0.6$ & $65.3^{\mathrm{b}} \pm 0.6$ & $60.4^{\mathrm{d}} \pm 0.3$ & 0.0055 \\
$\mathbf{5 - 6}$ weeks & $69.0^{\mathrm{d}} \pm 0.9$ & $78.3^{\mathrm{a}} \pm 0.7$ & $69.9^{\mathrm{cd}} \pm 0.7$ & $72.1^{\mathrm{b}} \pm 0.9$ & $70.2^{\mathrm{c}} \pm 0.6$ & 0.0055 \\
Overall mean & $56.0^{\mathrm{c}} \pm 0.3$ & $58.5^{\mathrm{a}} \pm 0.7$ & $57.5^{\mathrm{b}} \pm 0.7$ & $57.2^{\mathrm{b}} \pm 0.7$ & $55.2^{\mathrm{c}} \pm 0.2^{2}$ & 0.0032 \\
\hline a---d
\end{tabular}

Means $( \pm \mathrm{SE})$ in the same row with different superscripts are significantly different $(\mathrm{P} \leq 0.05)$.

Values in each row are means for 3 replicates of each treatment ( 30 birds per each).

G1 to G5: Control, $200 \mathrm{mg}$ Neomycin/kg diet, $1 \mathrm{~g}$ probiotic/kg diet, $1.5 \mathrm{~g}$ probiotic/kg diet, $2 \mathrm{~g}$ probiotic/kg diet, respectively.

Gaskins et al. (2002) stated that the dietary supplementation of probiotic increased growth performance in broilers. Casas et al. (1998) demonstrated that the turkey given Lactobacillus reuteri had better body weight gain by $4.8 \%$ at 120 days of age as compared to that of birds fed the control diet. Similarly, Lan et al. (2003), reported that broiler chickens given Lactobacillus agili and Lactobacillus salavarius had significantly had increased body weight gain (BWG) by $10.7 \%$ than the control. Jalaludeen et al. (2005) reported that the $0.025 \%$ probiotic supplemented birds had significantly higher BWG than that the control. In contrast, Maiolino et al. (1992) found no significant differences in weight gain of chicken given diet with or without Lactobacillus cultures. Lima et al. (2003) showed also similar body weight gain in birds supplemented or not with probiotics.

\section{Mortality rate}

The total mortality rate of birds in $\mathrm{G} 4(1.5 \mathrm{~g}$ probiotic/kg diet) during 6 weeks experimental period was lower than those of the other groups (Table 2). The results of numerous studies showed that probiotics had positive effects on health and immune response (Griggs and Jacob, 2005). The authors attributed the improved performance of chickens fed probiotics to the microstructures in the intestine, where the villus height and the goblet cell numbers increased, while the crypt depth is decreased. They added that probiotics improved the morphology of the intestinal tract which improved the absorption of the nutrients. They also reported that, probiotics had the potential to reduce the risk of infection by pathogens and to eliminate the antibiotic resistance among pathogenic organisms.
Furthermore, the carcass contamination by gutassociated pathogens appeared to be reduced and therefore public health concerns are decreased. However, many researchers reported that dietary antibiotics were associated with the inhibition of pathogen growth (Gaskins et al., 200 and; Jalaludeen et al., 2005). Similarly, the findings of Sun et al. (2005) indicated that birds fed diets free of antibiotic growth promoters resulted in higher mortality than did the dietary feeding with an antibiotic.

\section{Feed intake:}

The supplementation of both antibiotic and probiotics did not affect feed intake (Table 4). These results are were similar to those of ContrearasCastillo et al. (2008) who reported that FI of birds fed probiotics was similar to that of birds fed the control diet in all rearing stages. However, the results of Balevi et al. (2000) indicated that supplementation with probiotic at a level of $0.5 \mathrm{~g} / \mathrm{kg}$ diet caused some improvement in feed intake. Regarding ling the antibiotic effect, Contrearas-Castillo et al. (2008) citied that birds fed zinc bacitracin (antibiotic) during 1-4 days rearing period had the highest FI as compared to birds fed probiotic and control diets $(\mathrm{P}<0.05)$, whereas during $1-14$ and 1-28 days, the FI of zinc bacitracin group was similar to those of probiotics groups (1g probiotic/kg diet and $0.5 \mathrm{~g}$ probiotic/kg diet) but higher than both of the control or $0.05 \mathrm{~g}$ probiotic $/ \mathrm{kg}$ diet groups $(\mathrm{P} \leq 0.05)$. Also, Ignatova et al. (2009) reported administered that using probiotic in broilers diet affected positively their FI $(\mathrm{P} \leq 0.05)$ by about $7.8 \%$ more than of the control diet. Similar results in chickens fed probiotics were reported by Mountzouris et al. (2007). 
Table 4. Feed intake (g/bird/day) as affected by dietary Neomycin antibiotic and different levels of probiotics

\begin{tabular}{lrrrrrr}
\hline $\begin{array}{c}\text { Treatment } \\
\text { Age }\end{array}$ & G1 & G2 & G3 & G4 & G5 & $\begin{array}{c}\text { Significance } \\
\text { level }\end{array}$ \\
\hline 0 -2 weeks & $62.1 \pm 0.7$ & $55.5 \pm 1.6$ & $56.3 \pm 2.8$ & $56.4 \pm 1.6$ & $53.1 \pm 2.2$ & 0.0697 \\
3-4 weeks & $115.2 \pm 0.3$ & $116.2 \pm 0.9$ & $111.8 \pm 1.5$ & $11.1 \pm 2.8$ & $112.4 \pm 1.6$ & 0.1907 \\
5-6 weeks & $183.8 \pm 1.5$ & $186.7 \pm 0.7$ & $184.4 \pm 1.0$ & $180.7 \pm 1.1$ & $183.3 \pm 3.5$ & 0.3275 \\
\hline Overall mean & $120.4 \pm 0.8$ & $119.5 \pm 0.5$ & $117.5 \pm 0.6$ & $116.1 \pm 1.3$ & $116.3 \pm 2.2$ & 0.1211 \\
\hline
\end{tabular}

G1 to G5: Control, $200 \mathrm{mg}$ Neomycin/kg diet, $1 \mathrm{~g}$ probiotic/kg diet, $1.5 \mathrm{~g}$ probiotic/kg diet, $2 \mathrm{~g}$ probiotic/kg diet, respectively. Values in each row are means for 3 replicates of each treatment (30 birds per each).

Table 5. Feed conversion ratio (g feed/g gain) as affected by dietary Neomycin antibiotic and different levels of probiotics

\begin{tabular}{lcccccc}
\hline $\begin{array}{c}\text { Treatment } \\
\text { Age }\end{array}$ & G1 & G2 & G3 & G4 & G5 & $\begin{array}{c}\text { Significance } \\
\text { level }\end{array}$ \\
\hline 0 -2 weeks & $1.68^{\mathrm{a}} \pm 0.01$ & $1.63^{\mathrm{a}} \pm 0.02$ & $1.55^{\mathrm{b}} \pm 0.02$ & $1.65^{\mathrm{a}} \pm 0.02$ & $1.53^{\mathrm{b}} \pm 0.03$ & 0.0011 \\
$\mathbf{3 - 4}$ weeks & $1.88^{\mathrm{a}} \pm 0.03$ & $1.85^{\mathrm{a}} \pm 0.01$ & $1.68^{\mathrm{b}} \pm 0.02$ & $1.71^{\mathrm{b}} \pm 0.03$ & $1.87^{\mathrm{a}} \pm 0.02$ & 0.0002 \\
$\mathbf{5 - 6}$ weeks & $2.67^{\mathrm{a}} \pm 0.04$ & $2.38^{\mathrm{c}} \pm 0.03$ & $2.66^{\mathrm{a}} \pm 0.03$ & $2.52^{\mathrm{b}} \pm 0.04$ & $2.67^{\mathrm{a}} \pm 0.04$ & 0.0003 \\
\hline Overall mean & $2.16^{\mathrm{a}} \pm 0.01$ & $2.04^{\mathrm{b}} \pm 0.02$ & $2.05^{\mathrm{b}} \pm 0.02$ & $2.03^{\mathrm{b}} \pm 0.01$ & $2.12^{\mathrm{a}} \pm 0.02$ & 0.0006 \\
\hline
\end{tabular}

Means $( \pm \mathrm{SE})$ in the same row with different superscripts are significantly different $(\mathrm{P} \leq 0.05)$

G1 to G5: Control, $200 \mathrm{mg}$ Neomycin/ $\mathrm{kg}$ diet, $1 \mathrm{~g}$ probiotic/kg diet, $1.5 \mathrm{~g}$ probiotic/kg diet, $2 \mathrm{~g}$ probiotic/kg diet, respectively.

\section{Feed conversion ratio}

Data on feed conversion rate are presented in Table 5. During 0-2 weeks of age, the birds of G3 and G5 had significantly better feed conversion ratio (FCR) than those of the other groups (G1, G2 and G4). During 3-4 weeks of age, birds of G3 and G4 had significantly better FCR than those of the other groups (1, 2 and G5). During 5-6 weeks of age, the birds of G2 had significantly better FCR than those of G1, G3, G4 and G5, while birds of G3 had significantly better FCR than those of birds in groups 1,3 and 5.

The birds fed antibiotic diet (G2) or those received levels of $1 \mathrm{~g}$ and $1.5 \mathrm{~g}$ probiotic/ $\mathrm{kg}$ in diets (G3 and G4) had significantly better FCR during the period 0-6 weeks than those of birds fed the control (G1) and $2 \mathrm{~g}$ probiotic/kg diets (G5). These results agreed with those of Gaskins et al. (2002), who stated that the dietary antibiotic was associated with an improvement in poultry FCR and the inhibition of pathogens growth. Contrearas-Castillo et al. (2008) reported that birds fed the control diets during the experimental period had significantly lower FCR than in birds fed antibiotic and $1 \mathrm{~g}$ probiotic/kg diet. The FCR was not different among control, $0.5 \mathrm{~g}$ probiotic $/ \mathrm{kg}$, and $0.05 \mathrm{~g}$ probiotic $/ \mathrm{kg}$ diet groups. In contrast, some researchers did not find statistical differences in FCR of birds during the rearing period among the experimental groups supplemented with probiotics, antibiotics, or without antibiotics (Correa et al. 2003). Others reported that the dietary supplemented antibiotics were associated with an improvement in poultry growth and FCR due to the inhibition of pathogen growth (Gaskins et al., 2002).

Previous results of Balevi et al. (2000) indicated that supplementing the diet with a probiotic at a level of (at $0.5 \mathrm{~g} / \mathrm{kg}$ diet) caused some improvement in FCR. Similarly, Ignatova et al. (2009) indicated administered that supplementing probiotic in broilers diet affected positively the FCR $(\mathrm{P}<0.05)$ by $8.0 \%$ as compared to the control diet. Also, numerous studies showed that probiotics had a positive effect on FCR of chicken (Mountzouris et al., 2007) and on health and immune response (Griggs and Jacob, 2005).

The improvement in FCR due to the beneficial effects of probiotics represented in toxin neutralization, prevention of development and multiplication of specific bacteria, change in microbial metabolism and immunity stimulation (Fuller, 1989), in addition to the prevalence of their population against the adverse pathogens of digestive system (Bilgili and Moran, 1995). The authors stated that the prevalence of useful microorganism over harmful ones, improved FCR. Also, Tannock et al. (1990) reported that lactic acid producing bacteria are represented among the members of the normal microflora and are capable to inhibit the digestive tract pathogens of many animal species. Bilgili and Moran (1995) and EL-Nagmy et al. (2007) demonstrated that adding whey to the diet, contributes to digestibility and absorption of the nutrients in diet due to its capability to produce an acidic condition which is suitable for growth of lactobacillus and increase the digestibility and absorption of the nutrients.

\section{Caracas criteria:}

Data of carcass criteria are presented in Table (6). The differences in the percentages of dressed carcass, body organ weights (gizzard liver, heart, giblets, and spleen) and body organ lengths (intestines and ceca) were insignificant among all groups. The abdominal 
fat percentage in G1 and G4 were lower than those of the other groups. These results are in agreement with those of Mandai et al. (1994), Ayasan and Okan (2001), Islam et al. (2004), and Ignatova et al. (2009). Ayasan and Okan (2001) investigated the effect of four levels of probiotic on fattening performance and carcass characteristics of Japanese quails. The results showed that the carcass characteristics were not affected by the probiotic supplementation. Also, Ignatova et al. (2009) found no significant differences in the carcass yield among the control and probiotic experimental groups. In addition, Mandai et al. (1994) found that probiotics feeding did not have any influence on the carcass yield. Islam et al. (2004) found that supplementation of probiotics had no effect on the weight of internal organs.

Table 6. Dressed carcass, body organ weight, abdominal fat and body organ length as affected by dietary antibiotic Neomycin and different levels of probiotics

\begin{tabular}{|c|c|c|c|c|c|c|}
\hline $\begin{array}{l}\text { Treatment } \\
\text { Items }\end{array}$ & G1 & G2 & G3 & G4 & G5 & $\begin{array}{c}\text { Significance } \\
\text { Level }\end{array}$ \\
\hline $\begin{array}{l}\text { Dressed carcass } \\
\text { (including giblets) } \\
(\%)\end{array}$ & $79.5 \pm 1.0$ & $79.5 \pm 0.6$ & $79.1 \pm 0.6$ & $80.0 \pm 1.0$ & $78.3 \pm 0.6$ & 0.6011 \\
\hline Abdominal fat (\%) & $0.76^{\mathrm{c}} \pm 0.05$ & $1.40^{\mathrm{a}} \pm 0.04$ & $1.37^{\mathrm{a}} \pm 0.08$ & $0.91^{\mathrm{c}} \pm 0.03$ & $1.20^{\mathrm{b}} \pm 0.04$ & 0.0001 \\
\hline \multicolumn{7}{|c|}{ Body organ weights (\%) } \\
\hline Gizzard & $1.4 \pm 0.1$ & $1.3 \pm 0.1$ & $1.5 \pm 0.1$ & $1.4 \pm 0.1$ & $1.6 \pm 0.1$ & 0.1719 \\
\hline Liver & $2.1 \pm 0.2$ & $1.9 \pm 0.1$ & $1.9 \pm 0.1$ & $2.1 \pm 0.1$ & $1.9 \pm 0.1$ & 0.1719 \\
\hline Heart & $0.6 \pm 0.1$ & $0.5 \pm 0.1$ & $0.6 \pm 0.1$ & $0.7 \pm 0.1$ & $0.4 \pm 0.1$ & 0.5290 \\
\hline Giblets & $4.1 \pm 0.09$ & $3.7 \pm 0.09$ & 4. $0 \pm 0.18$ & $4.2 \pm 0.11$ & $3.9 \pm 0.07$ & 0.1500 \\
\hline Spleen & $0.18 \pm 0.03$ & $0.16 \pm 0.03$ & $0.18 \pm 0.02$ & $0.23 \pm 0.03$ & $0.23 \pm 0.01$ & 0.3019 \\
\hline \multicolumn{7}{|c|}{ Body organ length of intestines (cm) } \\
\hline Intestines & $227.7 \pm 6.4$ & $218.7 \pm 4.0$ & 194. $7 \pm 2.0$ & 203. $7 \pm 1.0$ & 212. $3 \pm 4.0$ & 0.5364 \\
\hline Ceca & $40.3 \pm 0.3$ & 44. $7 \pm 2.9$ & $35.0 \pm 2.9$ & $37.7 \pm 2.6$ & $41.3 \pm 1.2$ & 0.2608 \\
\hline
\end{tabular}

Means $( \pm$ SE) in the same row with different superscripts are significantly different $(\mathrm{P} \leq 0.05)$.

Values in each row are means for 3 replicates of each treatment ( 9 birds per each).

G1 to G5: Control, $200 \mathrm{mg}$ Neomycin/ $\mathrm{kg}$ diet, $1 \mathrm{~g}$ probiotic/kg diet, $1.5 \mathrm{~g}$ probiotic/kg diet, $2 \mathrm{~g}$ probiotic/kg diet, respectively.

\section{CONCLUSION}

From the obtained results, it can be concluded the supplementation with of $1.5 \mathrm{~g}$ probiotic/ $\mathrm{kg}$ diet as an alternative to antibiotics in broilers is highly recommended to obtain higher growth performance, improved feed conversion and lower mortality, without adverse effect on abdominal fat and carcass traits.

\section{REFERENCES}

Ayasan T. and F. Okan, 2001. The effect of a diet with different probiotic (Protexin) levels on the fattening performance and carcass characteristics of Japanese Quails. Proceedings of $\mathrm{XV}^{\text {th }}$ European Symposium on the Quality of Poultry Meat, Kupadasi, Turkey, pp169- 174.

Balevi T., U.S. Ucan, B. Coskun, V. Kurtoglu and S. Cetingul, 2000. Effect of a commercial probiotic in the diet on performance and humoral immune system in layers. Hayvancilik Arastirma Dergisi 10: 25-30.

Bilgili S.F. and E.T. Moran, 1995. Influence of whey and probiotic supplemented withdrawal feed on the retention of salmonella incubated into marked age broiler. Poultry Science, 69: 1670-1674. http://dx.doi.org/10.3382/ps.0691670.

Casas I.A., F.W. Edens and W.J. Dobrogosz, 1998. Lactobacillus reuteri: an effective probiotic for poultry and other animals. In: Salminen S, von Wright A, editors. Lactic Acid BacteriaMicrobiology and Functional Aspects. Marcel Dekker, Inc. New York, pp 475-518.

Contrearas-Castillo C.J., C. Brossi, T.C. Previero and L.C. Demattê, 2008. Performance and carcass quality of broilers supplemented with antibiotics or probiotics. Brazilian Journal of Poultry Science, 10 (4): $227-232$.

Corrêa G.S.S., A.V.C. Gomes, A.B. Corrêa, A.S. Salles and E.S. Mattos, 2003. Efeito de antibiotico e probiotics sobre o desempenho e rendimento de carcaça de frangos de corte. Arquivo Brasileiro de Medicina Veterinria e Zootecnica, $\quad 55 \quad$ (4): $\quad 467-473$. http://dx.doi.org/10.1590/S010209352003000400013.

Cyberhorse, 1999. International Animal Health Products. The Australian Company ACN 003185 699, Australia. http://www.cyberhorse.net.au/an/ protexin.htm. 
Duncan D.B., 1955. Multiple range and multiple tests. Biometrics, 11: 1-42. http://www.jstor.org/discover/10.2307/3001478?u $\mathrm{id}=3738504 \&$ uid $=2 \&$ uid $=4 \&$ sid $=2110325834094$ 3.

El-Nagmy, K.Y., A.A. Ghazalah, and A.S. Bahakim, 2007. The effect of probiotics supplement on performance of broiler chicks fed diets varying in protein content. $4^{\text {th }}$ World Poultry Conference, Sharm El-Sheikh, Egypt, pp 27-30,

Fuller R., 1989. Probiotics in man and animals. Journal Applied Bacterial, 66: 365-378. http://dx.doi.org/10.1111/j.13652672.1989.tb05105.x.

Gaskins H.R., C.T. Collier and D.B. Anderson. 2002. Antibiotics as growth promotants: Mode of action. Animal Biotechnology, 13: 29-42. http://dx.doi.org/10.1081/ABIO-120005768 PMid:12212942.

Gibson G.R. and M.B. Roberfroid, 1995. Dietary modulation of the human colonic microbiota: Introducing the concept of prebiotics. Journal Nutrition, 125: 1401-1412. PMid:7782892.

Griggs, J.P. and J.P. Jacob, 2005. Alternatives to antibiotics for organic poultry production. The Journal of Applied Poultry Research, 14: 150156.

Ignatova M., V. Sredkova and V. Marasheva, 2009. Effect of dietary inclusion of probiotic on chickens performance and some blood indices. Biotechnology in Animal Husbandry, 25 (5-6): 1079-1085.

International Animal Health, 1999. Protexin multistrain probiotic. Cyberhorse. http://wwwcyberhorse. net. au/ian// protexin.htm.

Islam M.W., M.M. Rahman, S.M.L. Kabir, S.M. Kamruzzaman and M.N. Islam, 2004. Effects of probiotics supplementation on growth performance and certain haemato-biochemical parameters in broiler chickens. Bangladesh Journal Veterinary Medicine, 2 (1): 39-43.

Jalaludeen A., M.K.A. Sabiha and V.K. Elizabeth, 2005. Effect of supplementation of probiotic on the growth performance of broiler chicken. Indian Journal Poultry Science, 40: 73-75.

Janardhana V., M.M. Broadway, M.P. Bruce, J.W. Lowenthal, M.S. Geier, R.H. Hughes and A.G.D. Bean, 2009. Prebiotics modulate immune responses in gut-associated lymphoid tissue of chickens. Journal Nutrition, 139: 1404-1409. http://dx.doi.org/10.3945/jn.109.105007 PMid:19474157.

Jernigan M.A. and R.D. Miles, 1985. Probiotic in poultry nutrition. A review. World's Poultry Science Journal, 41: 99-107.

http://journals.cambridge.org/action/displayAbstr act; jsessionid=9D303DC150183DD3476055F40F 1A7582. journals?fromPage $=$ online\&aid $=616112$.

Lan P.T., L.E.T. Binh and Y. Benno, 2003. Impact of two probiotic Lactobacillus strains feeding of fecal lactobacilli and weight gain in chickens. Journal of General and Applied Microbiology, 49 (1): 29-36. http://dx.doi.org/10.2323/jgam.49.29 PMid:12682864.

Lima A.C.F., J.M. Pizauro-JoNior, M. Macari and E.B. Malheiros, 2003. Efeito do uso de probiotic sobre o Desempenho e atividade de enzimas digestivas de frangos de corte. Revista Brasileira de Zootecnia, $32 \quad$ (1): 200-207. http://dx.doi.org/10.1590/S151635982003000100025.

Maiolino R., A. Fioretti, L.F. Menna and C. Meo, 1992. Research on the efficiency of probiotics in diets for broiler chickens. Nutrition Abstract Review Series, B, 62: 482.

Mandai S.K., I.K. Biswas and L. Mandal, 1994. Efficiency of different growth promoters on the performance of boilers. Indian Journal of Poultry science, 92: 13-17.

Mountzouris K.C., P. Tsirtsikos, E. Kalamara, S. Nitsch, G. Schatzmayr and K. Fegeros, 2007. Evaluation of the efficacy of a probiotic containing Lactobacillus, Bifidobacterium, Enterococcus and Pediococcus strains in promoting broiler performance and modulating cecal microflora composition and metabolic activities. Poultry Science, 86: 309-317. PMid:17234844.

National Research Council, 1994. Nutrient Requirements of Poultry. $9^{\text {th }}$ Review Edition, National Academy Press, Washington, D.C. http://www.lamolina.edu.pe/zootecnia/biblioteca2 012/NRC\%20Poultry\%201994[1].pdf.

SAS Institute, 2005. User's Guide: Statistics. Version 9.1. SAS Institute, Inc., Cary, North Carolina, USA.

http://support.sas.com/rnd/itech/updates/91/dev_g uide.pdf.

Sun X., A. McElroy, K.E. Webb, Jr., A.E. Sefton and C. Novak, 2005. Broiler performance and intestinal alterations when fed drug-free diets. Poultry Science, 84: 1294-1302. PMid:16156214.

Tannock G.W., R. Fuller and K. Pedersen, 1990. Lactobacillus succession in the piglet digestive tract demonstrated by plasmid profiling. Applied Environmental Microbial 56:1310-1316. PMid:2339885 PMCid:PMC184400.

Turnidge J., 2004. Antibiotic use in animalsprejudices, perceptions and realities. Journal Antimicrobial Chemother, 53: 26-27. http://dx.doi.org/10.1093/jac/dkg493PMid:14657093.

Yang Y., P.A. Iji, A. Kocher, E. Thomson, L.L. Mikkelsen and M. Choct, 2008. Effects of mannanoligosaccharide in broiler chicken diets on growth performance, energy utilisation, nutrient digestibility and intestinal microflora. British Poultry Science, 49: 186-194. http://dx.doi.org/10.1080/00071660801998613PMid:18409093. 
أداء وصفات الذبيحة لبداري التسمين والمضاف إليها البروبيوتيك أو المضاد الحيوي النيومايسين حاتم يوسف الحمادي، محمد الصغير محمد1، حسام حسن حساتين، حمدي أحمد حسن2 1- قسم إنتاج الدواجن ، كلية الزراعة ، جامعة أسيوط ، 71526 أسيوط، مصر، 2- قسم الإنتاج الحيواني والدواجن ، كلية الزراعة ، جامعة

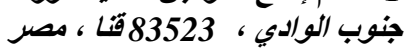

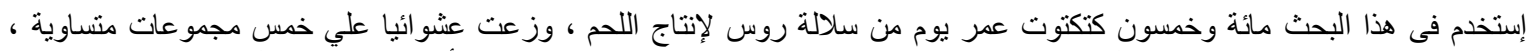

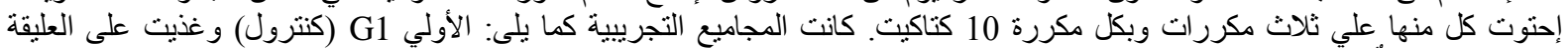

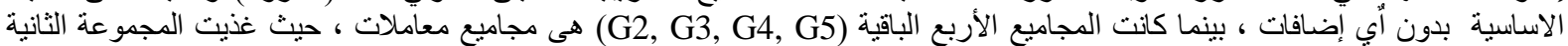

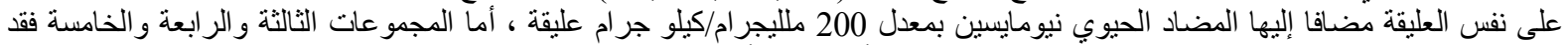

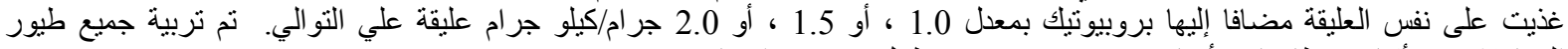

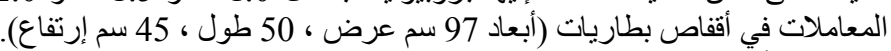

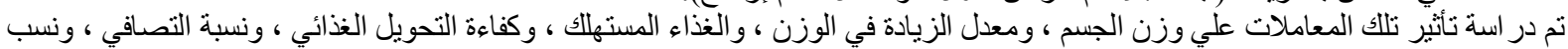

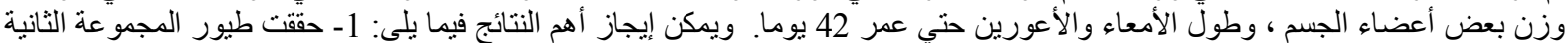

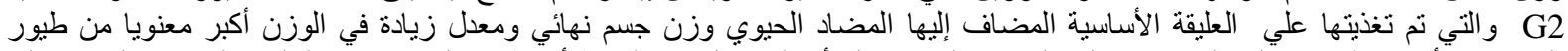

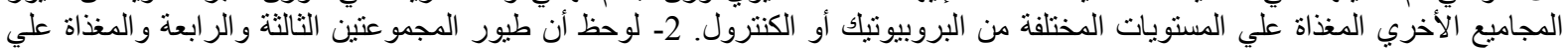

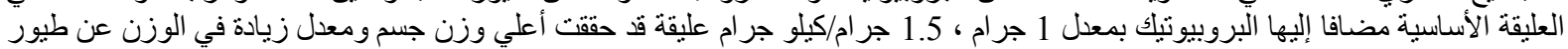

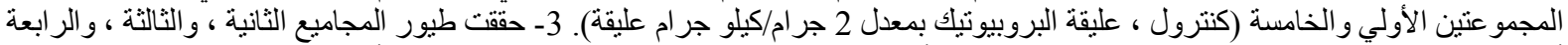

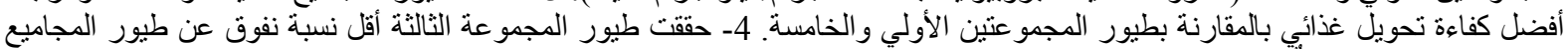

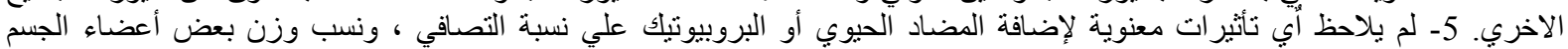

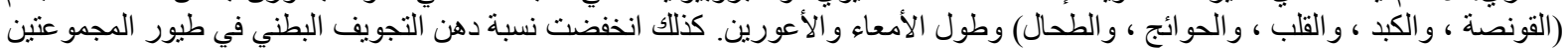
الأولي و الر ابعة عن المجاميع الاخري.

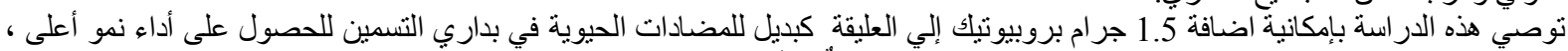

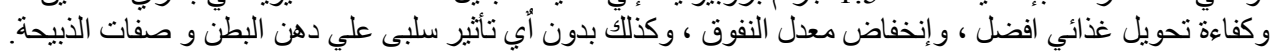

